\title{
THE ROLE OF Al-HISBAH IN IMPLEMENTATION OF BUSINESS ETHICS IN TRADITIONAL MARKETS
}

\author{
${ }^{1}$ Moch. Khoirul Anwar*, ${ }^{2}$ A'rasy Fahrullah, ${ }^{3}$ Ahmad Ajib Ridlwan, ${ }^{4}$ Muhammad Hasan \\ Muzaki \\ ${ }^{1234}$ Faculty of Economics and Business, Universitas Negeri Surabaya \\ *Corresponding author e-mail: khoirulanwar@unesa.ac.id
}

\begin{abstract}
Abstack
This study aims to analyze the implementation of business ethics in traditional markets and analyze the role of al-Hisbah in the implementation of business ethics in the Wonokromo traditional market in Surabaya. This type of research is field research. The data collection methods are observation, interview, and study literature. The research result implies information about the traditional market sellers' understanding of business ethics that very diverse. Although some sellers do not know theoretically about business ethics, they implement the ethical business value because of their obedience to religious values taught by their families. The function of Al-Hisbah in the Wonokromo market has been going well despite some shortcomings that might able to be managed by supervision in terms of price, size/scale, and quality of goods. The implication of this research is its contribution to the development of Islamic Economics science, and input for stakeholders incuding market management and city government who involved in socialization and implementation business ethics at traditional markets.
\end{abstract}

\section{Keywords: Al-Hisbah, Implementation, Business Ethics, Traditional Market}

\section{Introduction}

Islam teaches its adherents to apply religious teachings in kaffah (perfect, totality, and overall). As his words in Q.S Al-Baqarah verse 208, which means: "O people of faith, enter Islam in a kaffah, and do not follow the steps of Satan. Really, he is a real enemy to you". This verse explained that Islam had governed the way of thinking, behaving and acting of a Muslim, including in carrying out economic, social, political, or other activities in order to worship God (Ancok \& Suroso, 2001). The perfection of Islam in question is not only related to worship (hablu minallah) but also related to muamalah (hablu minannas).

One of the muamalah domains is trading or doing business. Zafar \& Sulaiman (2019) explain that religion not only brings an ethical dimension and but also morality values in business. Islam encourages every businessperson to uphold the values of morality, which include honesty, fairness, and transparency. These values are indispensable and become the responsibility of every market participant as their reflection of a Muslim's faith in Allah. Almoharby (2011) states that ethics in business can be achieved if someone has full faith in his God. Floren, Rasul, \& Gani (2019) state that the level of religiosity will influence businessmen's behavior in doing business operations, which later impacts consumers and potential customers. Aydin (2020) states that Muslims carry out activities under their level of faith. Muslims are always encouraged to become sellers, according to Shinkafi \& Ali (2018), which states that Islam prevents laziness and dependence, but encourages people to become entrepreneurs who need

Received: 2020-04-04 | Reviced: 2020-04-30 | Accepted: 2020-05-01

Indexed : Sinta, DOAJ, Garuda, Crossref, Google Scholar | DOI: https://doi.org/10.29313/amwaluna.v4i2.5869 
government support in the financial, social and legal fields. In Islam, business activities are not only beneficial to the world but also as a field of worship for Muslims, so they become successful entrepreneurs in the afterlife (Zulkifli \& Saripudin 2015). Hoque, Mamun, \& Mamun (2014) explains that business success also needs to be supported by a responsive and wise government in determining policies relating to the business of its people.

Every market participant must personally recognize the implementation of business ethics in the life of trading in the market. It means every seller may trade to profit as much as possible, but Islam is not just looking for maximum profit but also a blessing. Abuznaid (2009) revealed that applying Islamic business ethics became the foundation for business people to gain success. Mahyarni, Meflinda, \& Indrayani, (2018) state that the spiritual values of a Muslim entrepreneur are not only improving performance and business but also require the government's role in implementing entrepreneurship development policies such as training, capital subsidies, and information disclosure.

Moreover, Islam forbids Muslims to work at will to achieve their desires by justifying all means such as fraud, cheating, false oaths, usury, bribes, and other vanity acts. This is following Hassan (2016), which states that the Islamic economy aims to eliminate inequality, injustice, exploitation, and oppression in society. Therefore, in Islam, there is a limitation or dividing line between what is permissible and what is not permissible, which is right and wrong orhalal and haram. Nedelko, Mulej, \& Potocan (2017) states that the application of Islamic business ethics in a company is proven ableto improve the performance of employees and achieve the company's vision. This proves that it is necessary to apply Islamic business ethics in trading practices to improve the welfare of sellers (Anwar, et al., 2020). Besides, according to Abbas et al. (2019), to achieve business success, Islamic business ethics is needed to fulfill customer satisfaction and to achieve business targets.

Some empirical evidence shows there has been an ethical shift in doing business or trading in traditional markets, for example, sellers who reduce the scales, sellingchicken that is not fresh, ham, borak(a harmful chemical that mixed in food, such as meatball or frozen fish). Meanwhile, in terms of financial access, there are still many sellers who borrow money from a loan shark. This shows a decrease in social responsibility, honesty, and fair competition in the trading process.On the other hand, the government has the task of supervising business practicesin traditional markets. The government has a great responsibility in upholding business ethics, so there are no parties harmed. In addition to overseeing business ethics practices, the government also has the duty and authority in prosecuting violations of business ethics committed by individuals or companies. The sanction for violation of business ethics is expected to have a deterrent effect so that the application of business ethics in traditional markets can run well.From the perspective of Islamic Economics, supervision of business ethics in traditional markets can be done by an institution called Hisbah. According to al-Mawardi in Jaelani (2013), Hisbah institution has three main authorities: the authority in upholding ethics related to fraud and reduction of measurements or scales; the authority in the enforcement of ethics associated with fraud in commodities and prices, such as reducing doses and scales on the market, selling expired foodstuffs; the authority associated with delaying debt payments when the borrower is unable to pay.

According to Dogarawa (2013), the role of Hisbah is significant to ensure the application of sharia teachings by the public in social and business interactions.Research on Hisbah is rarely done. Most research focuses on the 
behavior of sellers and buyers. Therefore, the urgency of doing this research is because Hisbah as an institution is less explored, especially the Hisbah's role in the traditional market of Surabaya that becomes the economic pillar of this city. This study will focus on Wonokromo Market, where many many sellers of various types of goods are traded in fierce competition. Wonokromo Market is one of the well-known traditional markets in Surabaya besides Turi Market and Atom Market. Located at the entrance of Surabaya City, the Wonokromo market has a strategic location since it has direct access from Malang, Sidoarjo, and Mojokerto.Wonokromo Market is located on the ground floor of the Darmo Trade Center, which reflected the harmonious integration of traditional and the modern market in this area.

This study aims to analyze the implementation of business ethics in traditional markets and analyze the role of Hisbah in the implementation of business ethics in the Wonokromo traditional market in Surabaya. The outcome of study is expected to provide information about understanding Islamic Business Ethics of traditional market sellers in Wonokromo market and the role of Al Hisbah in carrying out control mechanisms for the application of this ethic. The implication of this research is its contribution to the development of Islamic Economics science, Islamic socio-economic development, and input for stakeholders incuding market management and city government who involved in socialization and implementation business ethics at traditional markets.

\section{Business Ethics}

Based on terminology, ethics comes from the ancient Greek language, the singular word of ethosmeans "the usual place of residence"; "pasture," "cage"; "customs," "character"; "feelings," "attitudes," "ways of thinking." Meanwhile, the plural world, ta etha, means "custom." This plural meaning becomes the background of the term "ethics" used by the great Greek philosopher Aristotle (384-322 BC.) as the term for "moral philosophy" (Bertens, 1993). In the Indonesian Dictionary (Indonesian Ministry of Education and Culture, 1988), "ethics" is explained by three meanings: 1) Knowledge about what is good and what is wrong and about moral rights and obligations (morals); 2) A collection of principles or values relating to morals; 3 ) The value of right and wrong adopted by a group or society. Thus, from this meaning, we can conclude that "ethics" are moral values or norms which become a guideline for a person or group of people in regulating their behavior.

In an Islamic perspective, "ethical behavior" is not only an individual behavior that acts correctly without truth value. Hence, Islam emphasizes the use of the word moral rather than ethics. In Islam, moral discourseas integration ofaqeedah and sharia. Morals are part of the commands and prohibitions of Allah SWT and should be implemented in individuals or the community practice. According to Ahmad (2018), the application of Islamic values in all activities is essential to get goodness between humans.

Thus, it can be understood that business ethics are the norms or ethical principles adopted by the business, both as an institution or organization, as well as in its business interactions with its "stakeholders." Ethics and ethical behavior become part of the company's culture and "built-in" as a behavior (behavior) in employees to the CEO. Even for entrepreneurs whose standards are not uniform or universal, there should be a minimum ethical standard. This universalism raises various perspectives of anentrepreneur in animating, operating and suing ethics to himselfin every single activity. Wirawan (2012)'s research results show that there are deviations of sharia 
values committed by sellers when practicing trading in the Wonokromo Market-for example, setting prices too high from the initial price, as well as fraud in setting the measurements/scales that usuallypracticed by the fruit sellers.

In contrast to Wirawan, the results of Amalia (2014)'s research showed that Creative Kampoeng, Madinah Bazaar, and Small Businesses in the UIN Jakarta Environment had implemented Islamic business ethics, both by employers and their employees. In conducting business and activities, business people in this market have understood and implemented Islamic principles or values based on the Qur'an and Hadith. The implementation of Islamic business ethics in this market includes four aspects: principles, management, marketing/advertising, and products/prices.

Moreover, the previous research conducted by Syaifullah (2014) results that buying and selling in Islam cannot be separated from the ethics that must be held by all parties in order to maintain the benefit of all people, which ultimately forms a safe, peaceful and honest market system and avoids the persecution system that will harm all parties. Prasetyo (2016) 's research shows that "X" Tour and Travel has implemented Shiddiq, Istiqamah, Fathanah, Amanah, and Tabligh in marketing communications.Furthermore, there is research by Ridlwan, Anwar, \& Fahrullah (2017) about the implementation of sharia values in Wonokromo Surabaya traditional market sellers. From the results of this study, it was concluded that there were sellers who behaved in deviations from the shari'a values of trading, including purposely reducing scale, selling goods that had expired, andpracticing dishonesty in mentioning the acquisition price of goods by sellers. Meanwhile, some sellers also not pay zakat, even though they know Islam suggests to pay zakat, to "clean" from forbidden elements in their asset (Fikriyah, Ridlwan, \& Suryaningsih, 2019).

\section{Hisbah concept}

In language, the word "Hisbah" comes from the Arabic word hasabayuhasibu-hasban-hisaban-hisbanan-

husbanan-hisbatan-hisabat, which means "wages" and "reward" (Ma'lûf, 1986: 132). Meanwhile, Ibn Manzhur (tt: 305) explains that the word al-Hisbah is derived from the word al-ihtisab, which means "charity" and "avoiding disgraceful deeds" that are immediately related to "gaining merit" and "effort to doing good things." Based on etymology, Mujahidin (2012) cites alMawardi's opinion that Hisbah is an "order to carry out good deeds that have already begun to be abandoned, and preventing evil deeds that have already begun to appear." Also, the Mujahideen quoted opinion from Ibn Khaldun, who stated that Hisbah was a religious duty to order the truth and forbid the negation. This becomes the obligation that centered on the problems of the Muslims. Therefore, those who must occupy such noble positions are someone (state leader or ordinary people) who can carry out these tasks and can help this institution work.

Contemporary scholars who explain the concept of Hisbahis Muhammad Mubarak. Halim (2011) cites Mubarak's opinion that Hisbah is administrative oversight carried out by the government by assigning particular employees or officials to supervise moral, religious, economic, or social problems in society. This role will realize justice and goodness based on the principles of Islamic teachings and traditions that recognized and accepted in all places and times.Furthermore, according to al-Mawardi in Jaelani (2013), Hisbah has three essential roles: (1) Dealing with charges related to fraud and reduction of measurements or scales; (2) Dealing with charges related to fraud in commodities and prices, such as selling expired goods;(3). Handling the charges associated with delaying debt repayment when borrowers unable to pay.

Therefore, the power of Hisbah is only limited to supervision to implement goodness and the prohibition of munkar 
Moch. Khoirul Anwar, The Role Of Al-Hisbah In Implementation Of Business Ethics In ....

(amar ma'ruf nahi munkar). In this case, ordering the deedin three contexts, namely:

1. Ordering deed related to the rights of Allah, for example, telling people to do Friday prayers and punish them if they do not do Friday prayers.

2. Ordering deedrelated to human rights, for example, telling people to pay the debt when they able to pay immediately.

3. Orderingdeed related to the shared rights between God and human rights. For example, telling parents/guardians to encourage their girls to marry men who have balanced kufu (comparable), this also applies equally to women who have divorced with their husbands.

\section{Methods}

This type of research is field research. As a practical source, this research was conducted at the Wonokromo traditional market in Surabaya and other places related to this research. Wonokromo Surabaya traditional market located on Jalan Wonokromo Jagir Surabaya. This market is under the management of the Regional Owned Enterprises (BUMD) PD. Pasar Surya, under the City Government of Surabaya.These types of collected data are observational data, interview data, and documentary data.

Research Approach and Data Collection Method

This research uses a qualitative approach because the data obtained are analyzed by a descriptive approach (Moleong, 2009). The paradigm used in this study is a naturalistic paradigm with a phenomenological approach that emphasizes the nature of social reality and learns what appears in society. By using this approach, it is expected to be able to interpret and explain the meaning contained in various Hisbah activities in the enforcement of business ethics in Traditional Markets Wonokromo Surabaya
(Suprayogo, 2010). In this study, researchers collected qualitative dataand quantitative data that calculated not with proof of direction for a prediction but only for supporting the phenomenon of qualitative analysis and the stability of the conclusions of the study.

\section{Data Analysis}

According to Nasution (2006), the data analysis in a qualitative study is openended and inductive. Therefore, with an inductive mindset, the data obtained in this study will be analyzed descriptively and qualitatively. First, the authors applied content analysis (content analysis) by analyzing the data content (messages) of communication or phenomenon (Muhajir, 1990). Content analysis a technique for making objective and systematic inferences by identifying the specific characteristics of the message or data to be studied (Holsti, 1969). Second, researchers will use synthesis analysis, which is an analysis that seeks to examine as carefully as possible theses developing economic empowerment efforts carried out by Islamic religious institutions in East Java, to further search for antithesis so that new theses appear to meet the objectives of this study (Van Laer, 1956).

\section{Discussion}

Implementation of Business Ethics in Wonokromo Traditional Market

Market Seller Adherence To Applicable Regulations

Based on the results of interviews conducted to informants, there are differences between seller explanationwith our observation. Overall, sellers comply with the agreed rules between sellers and PD. Wonokromo Solar Market. This is consistent with the results of interviews with market sellers, "we will be subject to applicable rules, both religious and state rules." This shows that sellers obey the rules. This opinion is reinforced by the statement of the Head of the Supervision 
Unit that nosellers who committed serious violations. "So far,nosellers who committed serious violations related to the existing rules. "However, the statement is inversely proportional to observations around the Wonokromo market. Some sellers have not obeyed the rules, especially regulations related to market cleanliness, including throwing trash in the marketarea. This phenomenon can be seen in the location of the vegetable market and the chicken market.The existence of regulations in the market made to ensure the safety and equality of sellers and buyers. The results of interviews with sellers and supervisors illustrate that sellers generally comply with passed regulations. However, based on observations around the Wonokromo market, the phenomenon is the opposite. Some sellers break the rules, such as not throwing trash in its place. Also, the location of the chicken market was found to be incompatible with the process of cutting according to the rules.

Islam upholds a clean and healthy lifestyle. Rasulullah SAW taught his followers about the procedures for maintaining hygiene and sanitation (environmental cleanliness). Maintaining sanitation includes maintaining the cleanliness of water sources, public roads, shelter, house yards, mosques, and markets. Cleanliness in Islam has an important position asfigh of worship in Islam begins with a discussion of thaharah, which implies purity and cleanliness. Cleanliness is the principle of the realization of health; one of the greatest favors that Allah bestows on humans, as is the authentic hadith,"There are two favors that humans often neglect (loss) in that is healthy and free time (opportunity)." (Narrated by AlBukhari and Ahmad). To encouraging clean living, slaughtering methods are also regulated in Islam. The Islamic Sharia regulates the provisions of killing animals before consumption, namely by slaughtering. So that the blood in the animal's body can come out until the remaining meat, however, slaughtering animals must not be careless. In the provisions of the Shari'a, several veins must cut when animals are slaughtered for halal consumption.

Animal slaughtering is strictly regulated in Islam. The main factor is that terrestrial animals have blood and must be slaughtered. Slaughtering itself is permanently removing the spirits and blood of animals. There are sea animals whose blood is not punished by lawful despite being dead without being slaughtered:"It is from Abdullah bin Umar that the Messenger of Allah SA said,' It has been permissible for us to have two carcasses, a fish and a grasshopper"'(HR Ibn Majah, Ahmad, and Baihaqi). Dead animal (with an exception for fish and grasshopper) and blood is forbidden and repeated several times in the Qur'an, for example, verse:"Forbidden to you (eating) carcasses, blood, pork, (animal flesh) slaughtered on behalf of other than Allah ..." (QS: AlMaidah verse 3); "... Moreover, (forbidden) animals that are suffocated, beaten, fallen, gored, and pounced on by wild animals, except for those you have slaughtered ...". When the animal has been slaughtered on condition that (1) Hulqum, means broken or the place where the breath is coming out (2), cut Mari' or body part where food comes out and (3) Wadajain, means or veins on the right and left side of the animal's neck is cut; then the animal's meat becomes halal, fresh, nutritious and healthy.

\section{Market Seller's Integrity}

Furthermore, sellers in the Wonokromo Market have mainly practiced Islamic business ethics. Sellers practice Shari'ah values relating to the ethics of trading in Islam in daily trading practices. Among the behavior of sellers to consumers/buyers include the value of honesty, always providing the best service, not taking too many profits, so it does not becomeusury, which is forbidden in trading. It is also applied to sellers' behavior towards their fellows; for 
example, sellers apply Islamic values, including not being involved in unfair competition and maintaining good relations among each other. According to Selim \& Farooq (2020), a collaboration between people in business (sellers, Hisbah, and government) can eliminate the existing gaps in society and create business success.

This conclusion is supported by the results of interviews with sellers who show an attitude of integrity, including honesty, responsibility, fairness, and not deceptive.Sellers are very familiar with the values of integrity in trading practices. Sellers expressly do not want to cheat because it can harm others. "I do not want to cheat because religion forbids, I do not want to cheat because it harms others and that there is karma. "The attitude of sellers with integrity is supported by the statement of the Head of Supervision Unit that there have been no reports from buyers regarding fraud committed by sellers. "Until now, there has been no report from buyers that sellers have being cheated, market managers have provided weighing or measuring devices (providing buyers who need the certainty of the truth of goods that have been purchased at the seller's quantities)."

The results of field observations also reinforce this fact. Researchers buy goods on the market then weigh them again with scales that have passed the same test results.Based on interviews with sellers, supervisors, and direct observations in the field, it can be concluded that Wonokromo traditional market sellers have integrity, including honesty, responsibility, fairness, andnot being deceptive. The attitude shown by market sellers is under Islamic business ethics as taught by Rasulullah SAW.

According to Amalia (2014), the characteristics of Rasulullah's business are as follows:

1. The main principle in business is honesty. Honesty is the main requirement in business activities.
Rasulullah always teaches honesty in business practice:"It is not justified for a Muslim to sell a sale that has disgrace unless he explains his disgrace" (H.R. Al-Quzwani). "Who cheats us, then he is not our group" (H.R. Muslim).Rasulullah acts honestly in doing business. He forbade sellers from putting rotten goods at the bottom and new goods at the top of the display.

2. Do not commit perjury. The Messenger of Allāh actively violated the traffickers to commit perjury in conducting business transactions. In a narration of Bukhari, the Prophet said,"By committing perjury, goods are indeed sold, but the results are not a blessing." In the narration of the history of Abu Zar, the Messenger of Allah threatened with a painful punishment for those who swear falsely in business, and Allah will not care about it later on the Day of Judgment (H.R. Muslim). The practice of perjury in business activities today is often done because it can convince buyers, and in turn, increase purchasing power or marketing. However, it must be realized that although the benefits obtained are abundant, but the results are not a blessing.

3. The correct measurement, weight, and scale. In trading, the correct and right scales must take precedence. Allahsaid: "Woe to those who cheat, those who, when they receive a measure from someone else, ask to be fulfilled, and when they measure or weigh for others, they reduce" (Al-Qur'an, 83: 112).

4. Not doing ihtikar. Ihtikar is (piling up and storing goods within a specified period, with the aim that the price will one day go up and huge profits are obtained). Rasulullah strictly forbids such business behavior.

5. Must not vilify other people's business, so people buy to him. The Prophet Muhammad said, "Let not one of you sell intending to vilify what others sell" (H.R. Muttafaq 'alayhi). 


\section{The Role of Hisbah in Traditional Markets}

The existence of Hisbah in Traditional Markets

Wonokromo Traditional Market is managed under the Regional Company (PD) of the Surya Market, so the rules must also follow the PD Surya Market rules. Wonokromo Market does not recognize the term Hisbah, as stated by Mr. Ketut Suko, as the Head of the Wonokromo Market Unit, from the highest level to the lowest structural level in the market, there is no term Hisbahas supervising body.However, even though there is no unit calledHisbah, the activities related to Hisbah already exist, both regarding their roles, duties, and authority. Among these are the monitoring of measurements, the quality of goods, price control, order control, security, and market cleanliness. All these duties are implemented every day by market officers under the command and coordination of the Head of the Supervision Unit.Under observational data collected by researchers and obtained from informants, there are indeed market officers who always go around to monitor the market activities, especially those concerning market order and security. The informant also stated that he had seen supervisors or market officers who carry out their duties. Sellers often did not know that there were officers who always monitored their activities, so they felt they were never monitored. This is, as said by one of the sellers in Wonokromo Market, who stated: "I do not know if there is a market supervisor, what is important is I just sell, pay market retribution, do not act unlawfully."

Nevertheless, there are also sellers who aware of the market officers as stated by a seller: "Market officer just goes for a walk while looking our stuff." Some consider that market supervisors only work at the office, "Market supervisors work at the office, not here, the security guard does." Most of the informants from sellers in the Wonokromo market stated that market officials had carried out their roles well in order to maintain market order. This is following a statement delivered by one of the sellers: "Yes, just watch here, right here many (sellers) sell their product here (on the terrace), but now it is not allowed. If anyone selling here, they (will be) driven out (from the market) by officers". Therefore, even though in the term, there is no Hisbah in Wonokromo Market, there are market officers who play the role as the role of the Hisbah officer (Hasib). They provide oversight of price stability, quality control of merchandise, oversight of size/measurements/scales, and supervision of order, security, and cleanliness of the market.

The duties and roles carried out by these market officers are not different from the role of a Hisbah officer. Hisbah was an institution that had the authority to enforce Amar ma'rufnahi munkar, but this authority was very general, which covered all aspects of socio-economic and religious life. Then in its development,Hisbahauthority is also including to supervise the market and the behavior of the community in the market, both sellers and buyers, especially those related to use correct measurements and scales and overseeing buying and selling to eliminate fraud. Choudhury (1998) states that there is a need for government policies implemented in the market to make the ethical Islamic market that makes social, economic, and God's divine in a system. Hisbah is a pioneer of justice in the market essential in channeling government policy to sellers in the market. This is under the statement of Ramasamy \& Yeung (2016), which states that success in trade is inseparable from the government's participation in issuing policies that limit or support sales in the community. Sanusi (2008) emphasized that Hisbah played an essential role in controlling malpractice and one-sided activities carried out in the field.

Wonokromo market officers who conduct surveillance in the Wonokromo market are special officers who have been appointed by the PD. Surya Market. This confirms again that from the perspective of 
Islamic Economics, they are Hisbah officers. This is following the definition of Hisbah explained by Muhammad Mubarok in Halim (2011), that Hisbahhas an administrative rolethat assigned by the government to supervise morality, religion, economics, precisely to realize justice and virtues based on Islamic principles and law and community traditions.

\section{Monitoring for Price Stability}

One of the market officer tasks is maintaining price stability, especially the price of basic needs. According to information from the Head of Supervision Unit and the observer's data, price monitoring at the Wonokromo market conducted daily by:

1) Monitoring by looking around the market area. Every day, there are market officers who go around the market to check the market price, especially the prices of staple goods. Besides communication with sellers, officers also communicate with buyers randomly. The material of communication is about the prevailing market prices on that day.

2) "TV Pasar" or Market TV. In order to maintain price stability and provide price information and education to the public, PD Pasar Surya, through the Wonokromo Market office, provides services in the form of "TV Pasar." Every day,sellers and buyers in the Wonokromo market can see the development of commodity prices that are traded in the market, especially the prices of necessities in various markets in Surabaya through a program aired by "TV Pasar." Related to this program, the Head of the Wonokromo Market Unit explained, that with the "TV Pasar," visitors to the Wonokromo market could find out the commodities sold and their prices, so that the public was interested in buying. Besides, "TV Pasar"is functioning as a benchmark for commodity prices so that if there is a high price offer from the seller, the buyer can make an appropriate price quote, as shown on "TV Pasar."

3) Price Report to the Ministry of Industry and Trade. As mentioned above, some officers always go around every day to check commodity prices. The checking results are then reported to Disperindag (Department of Industry and Trade), both Surabaya City and East Java Province. Furthermore, after being reviewed by Disperindag, the price of the commodity is disseminated to the broader community through the mass media and the official website of Disperindag. The recording and reporting task done by the officer is based on Daud (2019) 's research, which states that the reporting or findings of the council are critical and contribute significantly to the government in determining the actions and policies issued.After seeing the results of the research, it can be understood that, in general, supervision carried out by market officers (Hisbah officers) was practiced directly by visiting the market area. Nevertheless, there is also indirect supervision by conducting counseling or coaching, providing leaflets about rules or appeals, through market television media and the provision of measuring, weighing, and measuring tools that are intended for buyers who are dissatisfied with measuring instruments, weigh and measurement that applied by seller.

Monitoring activities for price stabilitythat carried out by market officers on a macroeconomic basis are significant. It is because price stability, especially prices for necessities, can encourage the level of household consumption to grow optimally based on existing potential. Also, price stability is a prerequisite for sustainable economic growth and people's welfare improvement. Ahmed, Islam, Alabdullah, \& bin Amran (2018) explain that creating price stability through the sharia mechanism is very important to 
overcome price problems in the community.From the perspective of Islamic economics, price stability is also becoming a particular concern. Parakkasi \& Kamiruddin (2018) explains that Islam teaches the perfection of market mechanisms, which are natural phenomena. The perfection of market mechanisms results in fair prices, both for sellers and buyers. If the market mechanism is disrupted, even fair prices will not be reached. Fair prices will encourage market participants to compete correctly in accordance with market mechanisms. Therefore, the Islamic economic system strongly encourages the concept of a fair, transparent, and appropriate market price mechanism.

The concept of price in Islam refers to the hadith narrated by Abud Dawud from Friends of Anas bin Malik:

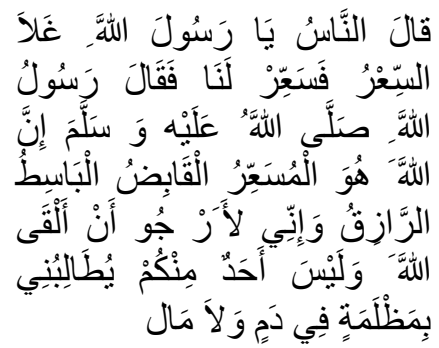

People say: "O Messenger of Allah, prices have gone up, then set a price for us." Then Rasulullah SAW said, "Verily, Allah has set prices, narrowed, and expanded, and I hope to meet with Allah while one of you does not sue me because of tyranny which results in bloodshed and property." (Narrated by Abu Dawud).

In this hadith, the Messenger of Allah did not determine the price. This shows that the price provisions should be left to the natural market mechanism. Rasulullah refused to set the price and said that the price in the market must not be determined because Allah was the one who determined it. The words of the Prophet contain the understanding that the market price is under the will of Allah SWT-sunnatullah or based on the law of supply and demand, as the Islamic economic theory of prices.

\section{Quality Control for Goods}

In order to maintain the quality or quality of merchandise, Wonokromo market officers also conduct quality control of goods traded in the Wonokromo Market. Supervision is carried out by checking directly the goods being traded, both in whole or randomly. Besides, counseling or guidance to sellers is also carried out in order to maintain the quality of their merchandise. For example, the Wonoromo Market has collaborated with Bidang Peternakan Dinas Ketahanan Pangan Kota Surabaya (Animal Husbandry Department of the Food Security Department of Surabaya City) to guide the Islamic slaughtering method for meat sellers in the Wonokromo Market. Besides, the Wonokromo Market is routinely collaborating with other agencies to maintain the quality of goods, such as collaborating with Food, Drug, and Cosmetics Agency (BPOM) to check the feasibility of goods, especially food and beverages sold at Wonokromo Market.

Supervision that carried out by Wonokromo market officers to thequality of the goods is an excellent effort to improve and maintain consumer confidence. Consumer satisfaction is important in order to maintain the sustainability of a trading business. According to Krisdianti \& Sunarti (2019), customer satisfaction is not easy to build but requires a long process, one of which is providing quality services and products to consumers. The Ministry of Trade of the Republic of Indonesia emphasizes that consumer protection provided to the public should be preventive such as protection before consumers suffer losses due to consuming goods and services. Therefore, supervision is implemented in two stages: (1) before the goods circulate in the market 
Moch. Khoirul Anwar, The Role Of Al-Hisbah In Implementation Of Business Ethics In ....

(pre-market stage) and (2) after the goods circulate in the market (Ministry of Trade of the Republic of Indonesia, 2015: ii).

In the perspective of Islamic Economics, giving satisfaction to customers is the same as making them happy with the transactions that have been made. As taught by Allah in the Qur'an alNisa verse 29:

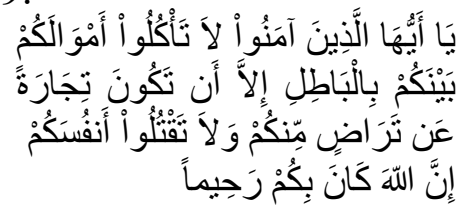

"O you who believe, do not unjustly eat your neighbor's property, except in the way of trade that applies with equal conscience between you. And do not kill yourself; surely Allah is the Most Merciful to you".

Al-Maraghy (2010) interpreted the above verse by explaining that a person must not trade in vanity or in a way that can harm others, including the trade that contains elements of fraud, lies, usury, and tyranny. Likewise,Islam also prohibited from spending property for something that is forbidden by Allah SWT and spending property excessively or wastefully.In the perspective of Islamic economics, maintaining thequality of the goods is maintaining halal goods, because halal and haram is a matter of principle in Islam. According to Anwar (2018), halal and haram enter the category of principle problems because there are so many verses of the Qur'an or hadith that govern and order to consume halal. Likewise, many verses of the Qur'an or hadith that prohibit us from consuming illicit products.

Among the verses of the Al Qur'an that command the consumption of halal products are: "O people, eat halal better than that which is on the earth, and do not follow the steps of shaitan; for indeed shaitan is the real enemy to you "(QS. alBaqarah [2]: 168). Likewise, the word of
Allah, "O you who believe, eat what is good than what we have allowed you" (QS. Al-Baqarah [2]: 172). Besides that, "And eat halal food again, which is good from what Allah has provided for you, and fear Allah whom you believe in Him" (QS. AlMa'idah [5]: 88).

Meanwhile, the verses of the $\mathrm{Al}$ Qur'an prohibit the consumption of illicit products: "O you who believe, indeed (drink) khamar, gamble, (sacrifice for) idols, draw lots of fate with arrows, is a heinous act including shaitan. So stay away from these deeds so that you get good luck "(Surah Al-Ma'idah [5]: 90).

There is also the word of Allah:

"Forbidden to you (eat) carcasses, blood, pork, (animal flesh) slaughtered on behalf of other than Allah, who choked, who was hit, who fell, who was horned, and who was pounced on by wild animals, except for those who had time to you slaughter it, and (it is forbidden for you) which is slaughtered for graven. And (also forbidden) to draw fate with arrows, (drawing fate with arrows) is wickedness. On this day the disbelievers are desperate to (defeat) your religion, therefore do not fear them and fear Me. On this day I have perfected for you your religion, and I have done enough for you in my faith, and for the pleasure of Islam, it has become a religion for you. So whoever is compelled to starve sins accidentally, surely Allah is Forgiving, Most Merciful "(Surah al-Ma'idah, 5:90)

From the understanding of these verses, halal food is good food that is allowed to eat according to Islamic teachings based onAl-Qur'an and hadith. Ibn Kathir (2000, VI: 415) defines halal as 
something useful and beneficial for the body and religion, while something that is forbidden by Allah is terrible and dangerous for the body and religion. Marzuki, Hall, \& Ballantine (2014) defines halal food as food that permissible to eat in Islam based on the Qur'an and hadith. E1 Garah, et al. (2012) added that the diversity of halal business in foreign countries requires regulations and certifications based on local customers to find compliance and mechanisms to assist the community in selecting and sorting products.

\section{Control to Scales and Measurement of Goods}

The market officer also supervises the appropriateness of the scales and measurements used by sellers in the Wonokromo market. According to $\underline{\mathrm{Abd}}$ Razak (2018)'s research which explains that good business does fulfill not only legal compliance with products but also legal compliance in implementing business operations. Supervision is usually done in the Wonokromo market by plunging directly into the field to re-measure or use UTTP (Ukur, Takar, TimbangdanPerlengkapannya/(Measuring, Scaling, Weighting, and Equipment)). In addition, officers also provide guidance or counseling related to the use of scales and measurements in accordance with existing regulations. This was also recognized by one of the Wonokromo market sellers, that there were always officers who inspected the weighing and measuring tools he used, at least once a year. As told by Mrs. Indah, a grocer in the Wonokromo market, "Usually, there are officers who check the weighting devices, once in several months."

Also, Wonokromo market officers also provide measurements and scales based on the rules to be provided for buyers who are in doubt about the size or scales used by the sellers. However, according to information from the Head of the Supervision Unit, ere have not been parties involved in a dispute related to the scaling, measuring, or weighing goods, both from the buyer and the seller. According to AlGhamdi, Sohail, \& Al-Khaldi (2007), the creation of consumer conduciveness over consumer dispute complaints against a business can be created by the active role of protection agents or Hisbah. Strong (1997) revealed that consumers also tend to prefer sellers who apply the principles of fairness in trading. Besides, Al-Kashif (2009) revealed that the value of honesty in business also tends to be more critical for success.

The next object of surveillance implemented by Wonokromo Market officers is the accuracy of measuring, scaling, and weighting tools used by sellers in the Wonokromo market. Supervision conducted by the market officer is based on Regulation of the Minister of Trade, Number: 26 / M-DAG / PER / 5/2017 about Legal Metrology Oversight. In Article 3, it is explained that the supervision of UTTP is carried out to ensure the use of UTTP based on the provisions, the correct measurements, weighting and scaling, and the presence of a statement or a written statement replacing the legal mark and cancel sign. Supervision of weighing equipment conducted by the market officer at the place of sellers is also based on the Minister of Trade Regulation. As stated in article 8, supervision is carried out on UTTP in the business place, a place to determine the size, scale for public use, a place to deliver goods, or place to determine fees or wages based on size or scales.In the perspective of Islamic economics, honesty in the scale is emphasized.

On the contrary, Islam strongly condemns people who cheat in a scale or measure. As the word of Allah SWT surah al-Shu'aro 181:

$$
\text { أَوْفُو ا الْكَيْلَ وَلَا تَكُوُنُوا مِنَ الُْخِِِِْْينَ }
$$

"Complete the measure and do not include those who harm." 
Moch. Khoirul Anwar, The Role Of Al-Hisbah In Implementation Of Business Ethics In ....

Ibnu Kathir (2000) interpreted the verse by stating that Allah ordered humans to improve the measurements or scales when measuring or weighing things for others, just as He also hoped for perfect scales when getting a part of another person. Do not let someone just expect a perfect scale or measure from someone else, while he does not want to perfect the scale or measure for someone else. There is also the Word of Allah in Surat alMuttaffifin verses 1-6:

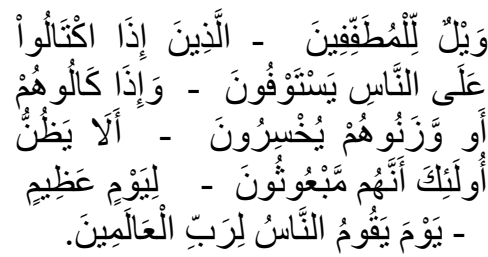

"It is a big accident for people who cheat. (i.e.) people who, when they receive doses from others they ask to be fulfilled. And if they measure or weigh for others, they reduce. These people do not think that they will be resurrected. One big day. (i.e.) the day (when) man stands before the Lord of hosts."

Al-Zuhaily (2011) interpreted that the above verse by explaining that people who commit fraud in scales or measures will get very painful torture from Allah SWT, although the cheating practice at a small level. They will later be raised on the Day of Resurrection by Allah SWT and will be held accountable for the fraudulent scales or measurements that they have done in the world. The above verse also illustrates how severe the threat is given to people who cheat on the scales and measurements because they have betrayed in carrying out the mandate and taking the rights of others. According to Tadajewski (2015), a business that is run without regard to ethics towards fellow human beings and ignores the trust of consumers will destroy the business itself.
Control of Order, Safety and Cleanliness of the Market

A market order, security, and cleanliness are essential things to be considered by traditional market managers, including the manager of the Wonokromo traditional market. They always try to improve the quality by structuring the market and evaluating it, both in terms of infrastructure/facilities and product quality improvement. The preventive and participatory actions that have been carried out by the Wonokromo market manager have always been to maintain market order, security, and cleanliness. They have individual officers to handle it.Security officers always go around the Wonokromo market to maintain order and security. When sellers disobeyed the rules, the security officer gives a warning. For example, when sellers sell their products in inappropriate places, the clerk immediately warns him. This is according to the results of observations of researchers and the recognition of one Wonokromo market seller who stated, "every day, there is asecurity guard who goes around the market, watch out for inappropriate negotiation (between seller and buyer."

The cleaning officers at Wonokromo Market always go around to maintain the cleanliness of the market. Also, in order to maintain market hygiene, trash bins are also placed in certain places. This makes it easier for sellers and buyers to dispose of trash in its place so that that market cleanliness can be maintained. As far as the researchers observed, the cleanliness in the traditional market was quite well maintained, except in the stall area where wet goods are sold, such as the area for selling meat, fresh fish, and so on. There is another area that is difficult to maintain cleanliness, such as the chicken slaughtering area. In that place, chicken blood and droppings were scattered everywhere. It was acknowledged by the Head of the Wonokromo Market that indeed one of the cleanliness problems was 
in the chicken slaughtering area, but every day the area was still cleaned.

The next object of supervision carried out by Wonokromo market officials is related to the order, security, and market cleanliness. All of this is done in order to provide comfort to all parties related to the market, both sellers and buyers or other visitors. Syafe'i (2013) 's research show that market safety and comfort has a positive and significant influence on people's interest to shop in these markets. Hasan (2013) also explained that business activities must be committed to maintaining ethics to the environment or in the sense of being aware of obligations to the environment as the impact of business activities. In line with research conducted by Malar (2008) which states that companies or business people are significant to understand that the earth to be explored but not exploited, because the impact will affect not only for business people but also for the surrounding community.

Besides, market cleanliness is also an important thing to always concerned with by the seller. A clean market will also add to the comfort of the community, both sellers and market visitors. So that traditional market hygiene and sanitation is also essential to realize food security in the market chain. There is also another hadith narrated by Imam Baihaqi, the Messenger of Allah said: "Islam is a religion (religion) that is clean/holy, so you should maintain cleanliness. Surely you will not enter heaven, except for those who are holy".

Furthermore, from an Islamic perspective, security is an important thing to consider. As the first request of the Prophet Ibrahim when in Mecca is to ask for security, as the word of Allah in Surat al-Baqarah verse 126

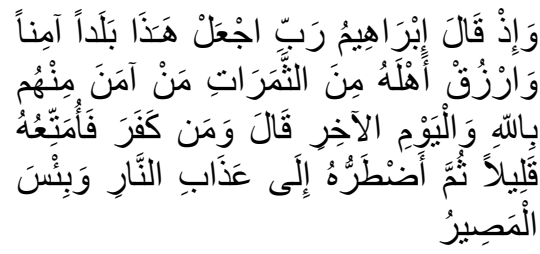

"And (remember), when Ibrahim prayed:" O my Lord, make this country a safe, secure country, and give sustenance from fruits to the inhabitants who believe among themselves to God and the day after. Allah said: "And to I who give disbelief a temporary pleasure, then I forced him to undergo the punishment of hell, and that is the worst place to return."

In the above verse, explicitly, the Prophet Ibrahim prioritized the request for domestic security rather than the request for fortune. Because after all, a person will not be able to enjoy the delicious food, drinks, or another fortune if he is always plagued with fear and worry in his life.

\section{Conclusion}

Traditional market sellers' understanding of business ethics is very diverse. That understanding underlies the sellers in behaving based on sharia values in trading. Some sellers do not know theoretically about business ethics, but they already implemented the sharia value learned fromreligious teachings by their parents. Nevertheless, some sellers know sharia values but do not implement them in daily trading practices. From the results of the study, it was found that the work of Hisbah in the Wonokromo market has been going well despite some shortcomings. Hisbah has fulfilled its authority in supervising the Wonokromo market includes; price, size/scale, and quality of goods.

Based on the conclusions above, it can be suggested thatthe awarenesssellers in traditional markets about business ethics should be improved in trade by conducting collaboration between MUI and Disperindag (Department of Industry and Trade). The cooperation can be in the form of routine socialization to sellers by inviting them to mosques around the market. Socialization can also be carried 
Moch. Khoirul Anwar, The Role Of Al-Hisbah In Implementation Of Business Ethics In ....

out through banner media, which contain writings or invitations to trade according to sharia principles.

\section{References}

Abbas, A., Nisar, Q., Mahmood, M., Chenini, A. \& Zubair, A. (2019). The role of Islamic marketing ethics towards customer satisfaction. Journal of Islamic Marketing, Vol. ahead-of-print No. ahead-of-print. https://doi.org/10.1108/JIMA-112017-0123

Abd Razak, A. (2018), Centralisation of corporate governance framework for Islamic financial institutions: Is it a worthy cause?, ISRA International Journal of Islamic Finance, 10 (1), pp.

36-51.

https://doi.org/10.1108/IJIF-08-2017$\underline{0020}$

Abuznaid, S. (2009). Business ethics in Islam: the glaring gap in practice.International Journal of Islamic and Middle Eastern Finance and Management, 2 (4), pp. 278-288. https://doi.org/10.1108/17538390911 $\underline{006340}$

Ahmad, M. (1999). Business Ethics in Islam. Pakistan: The International Institute of Islamic Thought.

Ahmad, N. (2018). Toward advancing debates on Islamic marketing: a renewed perspective. Journal of Islamic Marketing, 9 (1), pp. 152166. https://doi.org/10.1108/JIMA08-2016-0064

Ahmed, E., Islam, M., Alabdullah, T. \& bin Amran, A. (2018). Proposed the pricing model as an alternative Islamic benchmark. Benchmarking: An International Journal, 25 (8), pp. 2892-2912.

https://doi.org/10.1108/BIJ-04-20170077

Al-Ghamdi, S. M., Sohail, M. S. \& AlKhaldi, A. (2007), Measuring consumer satisfaction with consumer protection agencies: some insights from Saudi Arabia, Journal of Consumer Marketing, 24 (2), pp. 7179.

https://doi.org/10.1108/07363760710 737076

Al-Kashif, A. E. M. (2009), "Shari'ah's normative framework as to financial crime and abuse", Journal of Financial Crime, 16 (1), pp. 86-96. https://doi.org/10.1108/13590790910 924993

Al-Maraghy, A. M. (2010). Tafsir alMaraghy, Mesir : Mushtafa wa Auladihi.

Almoharby, D. (2011). The current world business meltdown: Islamic religion as a regulator. Humanomics, 27 (2), pp. 97-108.

https://doi.org/10.1108/08288661111 135108

Al-Zuhaili, W. (1989). al-Fiqh al-Islām wa Adillatuh. Jilid IV, Beirut: Dār alFikr.

Al-Zuhaily, W. (2011), Tafsir al-Munir; $f i$ al-Aqidah wa al-Syari'ah wa alManhaj, Damaskus: Dar al-Fikr.

Amalia, F. (2014). Etika Bisnis Islam: Konsep dan Implementasi. AlIqtishad: 6 (1)

Ancok, D. \& Suroso, F. N. (2001). Psikologi Islam. Yogyakarta : Pustaka Pelajar

Anwar, M. K. (2014). Ekonomi dalam Perspektif Islam. ISLAMICA: Jurnal Studi Keislaman, 3(1), 26-35, https://doi.org/10.15642/islamica.200 8.3.1.26-35

Anwar, M. K. (2018). The Urgency of Halal Assurance System for Product Reliability. International Journal of Islamic Business and Economics (IJIBEC), 2(2), 119-125, https://doi.org/10.28918/ijibec.v2i2.1 $\underline{388}$

Anwar, M. K., Fahrullah, A. \& Ridlwan A. A. (2018). The Problems of Halal Certification For Food Industry In Indonesia, International Journal of 
Civil Engineering and Technology, 9(8), pp. 1625-1632.

Anwar, M. K., Fahrullah, A., Ridlwan, A. A., Muzaki, M. H., Canggih, C. \& Kautsar, A. (2020). The Influence of Religiosity on Income and Prosperity: The Indonesian Context. Humanities \& Social Sciences Reviews, 8 (2), pp.213-222,

https://doi.org/10.18510/hssr.2020.82 25

Aydin, N. (2020). Paradigmatic foundation and moral axioms of ihsan ethics in Islamic economics and business, Journal of Islamic Accounting and Business Research, 11 (2), pp. 288308. https://doi.org/10.1108/JIABR12-2016-0146

Bertens, K. (1993). Prespektif Etika Esaiesai tentang Masalah Aktual, Yogyakarta: Kanisius.

Choudhury, M. A. (1998). Regulation and Deregulation In The Islamic Political Economy: Comparative Perspectives, Humanomics, 14(4). pp. 49-78. https://doi.org/10.1108/eb018817

Daud, D. (2019). The role of Islamic governance in the reinforcement waqf reporting: SIRC Malaysia case. Journal of Islamic Accounting and Business Research, 10 (3), pp. 392406. https://doi.org/10.1108/JIABR01-2017-0008

Dogarawa, A. B. (2013). Hisbah and the promotion of ethical business practices: A reflection for the shari'ah implementing states in Nigeria, International Journal of Islamic and Middle Eastern Finance and Management, 6 (1), pp. 51-63. https://doi.org/10.1108/17538391311 310743

El Garah, W., Beekun, R., Habisch, A., Lenssen, G., LozaAdaui, C., Ismaeel, M. \& Blaim, K. (2012). Toward applied Islamic business ethics: responsible halal business. Journal of Management Development, Vol. 31 No. 10, pp. 1090-1100. https://doi.org/10.1108/02621711211 281889

Fikriyah, K., Ridlwan, A. A. \& Suryaningsih, S. A. (2019). Islamic Work Ethics in Zakat Institution in Indonesia: How does it Affect Customer Loyalty? International Journal of Civil Engineering and Technology (IJCIET), 10(2), pp. 375381.

Floren, J., Rasul, T. \& Gani, A. (2019). Islamic marketing and consumer behaviour: a systematic literature review. Journal of Islamic Marketing, Vol. ahead-of-print No. ahead-ofprint. $\quad$ https://doi.org/10.1108/JIMA05-2019-0100

Halim, M. (2011). Eksistensi Wilayatul Hisbah dalam Sistem Pemerintahan Islam, Jurnal Ilmiah Islam Futura, 10 (2) $65-81$.

Haroen, N. (2007). Fiqih Muamalah, Jakarta: Gaya Media Pratama

Hasan, M. A. (2013). Berbagai Macam Transaksi dalam Islam. Jakarta: PT RajaGrafindoPersada

Hassan, A. (2016). Islamic ethical responsibilities for business and sustainable development", Humanomics, 32 (1), pp. 80-94. https://doi.org/10.1108/H-07-20150047

Holsti, C. R. (1969). Content Analysis for The Social Science and Humanities, Canada: Departement of Political Science University of British Colombia.

Hoque, N., Mamun, A. \& Mamun, A. M. A. (2014). Dynamics and traits of entrepreneurship: an Islamic approach. World Journal of Entrepreneurship, Management and Sustainable Development, 10 (2), pp. 128-142.

https://doi.org/10.1108/WJEMSD-042013-0027

Ibnu Katsir. (2000). Tafsir al-Qur'an al'Adhim. Yaman: Mu'assasah Qartabah. 
Moch. Khoirul Anwar, The Role Of Al-Hisbah In Implementation Of Business Ethics In ....

Jaelani, A. (2013). Institusi Pasar dan Hisbah : Teori Pasar dalam Sejarah Pemikiran Ekonomi Islam, Cirebon : Syaria Nurjati Press.

Kementerian Perdagangan RI. (2015). Analisis Evaluasi Pengawasan Barang Beredar dan Jasa, Jakarta : Badan Pengkajian dan Pengembangan Kebijakan Perdagangan Kementerian Perdagangan Republik Indonesia.

Krisdianti, D. L. \& Sunarti. (2019). Pengaruh Kualitas Pelayanan Terhadap Kepuasan Konsumen Pada Restoran Pizza Hut Malang Town Square, Jurnal Administrasi Bisnis (JAB) 70 (1). 36-44.

Ma'lûf, L. (1986). al-Munjîd fî al-Lughah wa al-A 'lâm, Bayrût: Dâr al-Mashriq.

Mahyarni., Meflinda, A. \& Indrayani, H. (2018). The investigation of the effects of spiritual values and behaviors on business development and performance of Muslim preneurship. International Journal of Law and Management, 60 (2), pp. 730-740.

https://doi.org/10.1108/IJLMA-032017-0027

Malar, S. M. S. (2008). The "ethics" of being profit focused. Social Responsibility Journal, 4 1/2, pp. 136-142.

https://doi.org/10.1108/17471110810 $\underline{856901}$

Marzuki, S. Z. S., Hall, C. M. \& Ballantine, P. W. (2014). Measurement of restaurant manager expectations toward halal certification using factor and cluster analysis. Procedia Social and Behavioral Sciences, 121, pp.: $291-303$.

Miles, B. M. \& Hubermann, M. A. (1992). Analisis Data Kualitatif. Penerjemah: Rohadi, R.T. UI Press: Jakarta.

Moleong, L. J. (2009). Metodologi Penelitian Kualitatif, Bandung: RemajaRosdakarya.
Muhajir, N. (1990).Metodologi Penelitian Kualitatif, Yogyakarta : Rakesaraseh.

Muhammad \& Lukman, F. (2002). Visi AlQur'an tentang Etika dan Bisnis. Jakarta : Salemba Empat

Mujahidin, A. (2012). Peran Negara dalam Hisbah. Al-Iqtishad, 4 (1)

Nasution, S. (2006). Metode Penelitian Naturalistik - Kualitatif, Bandung: Tarsito.

Nedelko, Z., Mulej, M. \& Potocan, V. (2017). How to requisitely holistically consider internal gaps of business ethic, Kybernetes, 46 (6), pp. 914-932. https://doi.org/10.1108/K$\underline{01-2017-0027}$

Parakkasi, I. \& Kamiruddin. (2018). Analisis Harga Dan Mekanisme Pasar Dalam Perspektif Islam, Jurnal Laa Maysir, 5(1). 107-120.

Peraturan Menteri Perdagangan Nomor : 26/M-DAG/PER/5/2017 Tentang Pengawasan Metrologi Legal.

Prasetyo. (2016). Islamic Business Ethics Implementation In Marketing Communication Of Hajj/Umroh Travel Agency "X" Surabaya. AlIqtishad: Jurnal Ilmu Ekonomi Syariah (Journal of Islamic Economics). 8 (1).

Qardhawi, Y. (1997). Norma dan Etika Ekonomi Islam. Jakarta : Gema Insani Press

Ramasamy, B. \& Yeung, M. (2016), Wooing the new Chinese businesses: five short-term policies to attract direct investment, Journal of Business Strategy, 37 (5), pp. 3-11. https://doi.org/10.1108/JBS-11-20150117

Ridlwan, A. A., Anwar, M. K. \& Fahrullah, A. (2017). Moslem Merchants in Traditional Market. Proceedings of the 1st International Conference on Islamic Economics, Business, and Philanthropy, Bandung : UPI.

Sanusi, M. M. (2008), Money laundering with particular reference to the banking deposit transactions: An 
Islamic perspective, Journal of Money Laundering Control, 11 (3), pp. 251-260.

https://doi.org/10.1108/13685200810 889399

Selim, M. \& Farooq, M. (2020), Elimination of poverty by Islamic value based cooperative model, Journal of Islamic Accounting and Business Research, Vol. ahead-ofprint No. ahead-of-print. https://doi.org/10.1108/JIABR-082018-0125

Shinkafi, A. \& Ali, N. (2018), Entrepreneurship Development in Islamic Economics, Rahman, A. (Ed.) New Developments in Islamic Economics, Emerald Publishing Limited, pp. 3-18. https://doi.org/10.1108/978-1-78756283-720181001

Strauss, A. \& Corbin, J. (2009). DasarDasar Penelitian Kualitatif, Yogyakarta:Pustaka Belajar.

Strong, C. (1997). The Problems of Translating Fair Trade Principles Into Consumer Purchase Behaviour. Marketing Intelligence \& Planning, $15 \quad$ (1), 32-37, https://doi.org/10.1108/02634509710 155642

Sudiran, F. (2006). Pembangunan Perkotaan ; Kajian Implementasi Kebijakan Pembangunan Kota Samarinda Menuju Kota yang Bersih dan Rapi, Disertasi, Universitas 17 Agustus 1945 Surabaya.

Sugiono. (2008). Metode Penelitian Kuantitatif Kualitatif dan $R \& D$. Bandung: Alfabeta

Suprayogo, I. \& Tobroni. (2010). Metodologi Penelitian Sosial Agama, Bandung: Remaja Rosdakarya.

Surahmad, W. (2000). Metodologi Penelitian, Jakarta: Balai Pustaka.

Syafe'i, M. (2013).Pengaruh Keamanan dan Kenyamanan Pasar Terhadap Minat Membeli Bagi Konsumen di Pasar Batik Klewer. Skripsi,
Surakarta : Universitas

Muhammadiyah Surakarta.

Syafie, R. (2006). Fiqih Muamalah. Bandung : Cv. Pustaka setia.

Syaifullah. (2014). Etika Jual Beli Dalam Islam.Hunafa: Jurnal Studia Islamika, Vol. 11, No. 2, Desember 2014

Tadajewski, M. (2015), The Complete English Tradesman - business relations, trust, and honesty or 'let's rethink the history of relationship marketing, Journal of Historical Research in Marketing, 7 (3), pp. 407-422.

https://doi.org/10.1108/JHRM-042015-0012

Van Laer, P. H. (1956). Philosophy of Science, Pittburgh :Dugnesne University.

Wirawan. (2009). Evaluasi Kinerja Sumber Daya Manusia. Salemba Empat: Jakarta.

Zafar, M. \& Sulaiman, A. (2019), CSR narrative under Islamic banking paradigm, Social Responsibility Journal, Vol. ahead-of-print No. ahead-of-print. https://doi.org/10.1108/SRJ-09-2018$\underline{0230}$

Zulkifli, M. \& Saripudin, O. A. S. S. (2015). Concept of Business Ethics In Islam - Approach To The Entrepreneur, Asian Economic and Social Society, 5(1), pp.13-18, https://doi.org/10.18488/journal.1006 /2015.5.1/1006.1.13.18 